\title{
Regulatory $T$ cells in radiotherapeutic responses
}

\section{Dörthe Schaue*, Michael W. Xie, Josephine A. Ratikan and William H. McBride}

Division of Molecular and Cellular Oncology, Department of Radiation Oncology, David Geffen School of Medicine, University of California at Los Angeles, Los Angeles, CA, USA

Edited by:

Sandra Demaria, New York University

School of Medicine, USA

\section{Reviewed by:}

Fatih Uckun, University of Southern

California, USA

Theresa L. Whiteside, University of

Pittsburgh Cancer Institute, USA

\section{*Correspondence:}

Dörthe Schaue, Department of Radiation Oncology, University of California at Los Angeles, 10833 LeConte Avenue, Los Angeles, CA 90095-1714, USA.

e-mail:dschaue@mednet.ucla.edu
Radiation therapy (RT) can extend its influence in cancer therapy beyond what can be attributed to in-field cytotoxicity by modulating the immune system. While complex, these systemic effects can help tip the therapeutic balance in favor of treatment success or failure. Engagement of the immune system is generally through recognition of damageassociated molecules expressed or released as a result of tumor and normal tissue radiation damage. This system has evolved to discriminate pathological from physiological forms of cell death by signaling "danger." The multiple mechanisms that can be evoked include a shift toward a pro-inflammatory, pro-oxidant microenvironment that can promote maturation of dendritic cells and, in cancer treatment, the development of effectorT cell responses to tumor-associated antigens. Control over these processes is exerted by regulatory $T$ cells (Tregs), suppressor macrophages, and immunosuppressive cytokines that act in consort to maintain tolerance to self, limit tissue damage, and re-establish tissue homeostasis. Unfortunately, by the time RT for cancer is initiated the tumor-host relationship has already been sculpted in favor of tumor growth and against immune-mediated mechanisms for tumor regression. Reversing this situation is a major challenge. However, recent data show that removal of Tregs can tip the balance in favor of the generation of radiation-induced anti-tumor immunity. The clinical challenge is to do so without excessive depletion that might precipitate serious autoimmune reactions and increase the likelihood of normal tissue complications. The selective modulation of Treg biology to maintain immune tolerance and control of normal tissue damage, while releasing the "brakes" on anti-tumor immune responses, is a worthy aim with promise for enhancing the therapeutic benefit of RT for cancer.

Keywords: radiation, danger, Tregs

\section{RADIATION AND "DANGER" SIGNALING}

Local RT has complex, systemic consequences (Formenti and Demaria, 2009) that, if harnessed properly have the power to significantly shape host-tumor relationships and ultimately affect treatment outcome. This review will focus on those aspects of RT that could translate into anti-tumor immunity, and their immune regulation.

Tissues that have been damaged by radiation display various "danger" signals to the immune system that can be secreted and/or released into extracellular spaces. The so-called DamageAssociated Molecular Pattern molecules (DAMPs; Shi et al., 2003; Lotze et al., 2007; Curtin et al., 2009; Sato et al., 2009). What characterizes DAMPs is that they are endogenous molecules that signal through a set of common pattern recognition receptors (PRRs; Matzinger, 2002; Lotze et al., 2007; Kawai and Akira, 2011), such as the Toll-like receptor (TLR) family (Medzhitov et al., 1997; Beutler, 2009), nucleotide binding oligomerization domain (NOD)-like, and retinoic acid inducible gene (Rig)like receptors (Meylan et al., 2006), and C-type lectins (Robinson et al., 2006). Once engaged, PPRs initiate signaling cascades to establish communications between immune cells through generally pro-inflammatory cytokine and chemokine networks. The system has evolved to recognize and deal with dangerous pathological situations, restore homeostasis, and to regenerate and heal tissues (Schaue and McBride, 2010; Schaue et al., in press).

Within tumors, DAMPs are generated by cell stress and death during progressive growth and increasing vascular abnormalities, and by oxidative damage and hypoxia (Ullrich et al., 2008; Sato et al., 2009). DAMP signaling and the cytokines they generate not only affect the content and function of innate immune cells within tumors, but also can play critical roles in the generation of adaptive immunity. This is because dendritic cells (DCs) have to mature to be competent at antigen-presentation, which requires pro-inflammatory "danger" signals (Banchereau and Steinman, 1998; Gallucci et al., 1999). Mature DCs are crucial for providing signal 2, the verification co-stimulatory signal that is needed to translate signal 1 (antigen) into a $\mathrm{T}$ cell-mediated immune response. Conversely, antigen-presentation in the absence of coaccessory signaling leads to immune tolerance (Steinman et al., 2003). In cancer treatment, the potential role of DAMP recognition and the initiation of adaptive anti-tumor immunity is seen in breast cancer patients with defective TLR-4 signaling who are less able to respond to standard therapy presumably because of a lack in tumor immune eradication (Apetoh et al., 2007). There is however a possible negative side to this equation as all cells, including 
tumor cells, express DAMP receptors of varying types which can drive tumor progression (Sato et al., 2009).

Tumor RT certainly will increase the amount of DAMPs released, but the extent to which it qualitatively and quantitatively changes DAMPs levels is not known, nor how such changes will affect the immune responses that are made. Exacerbation of the level of "danger" signaling in the tumor microenvironment by RT has however the potential to activate innate immune cells and link to the development of tumor antigen-specific, adaptive immunity. In support, we, and others, have observed that radiation can mature DCs, enhancing expression of numerous molecules that further aid immune recognition, such as MHC class I and II molecules, co-stimulatory CD80, cell adhesion molecules such as ICAM-1, integrins, and selectins, and damage recognition molecules such as phosphatidyl serine (Santin et al., 1996; Morel et al., 1998; Seo et al., 1999; Garnett et al., 2004; Reits et al., 2006; Tyurina et al., 2011), in addition to creating a pro-oxidant, proinflammatory milieu that encourages infiltration by immune cells (Lorimore et al., 2001; Lugade et al., 2005, 2008; Matsumura et al., 2008; Burnette et al., 2011). Overall, these responses seem to be a deliberate attempt by the tissue to improve immune cell access and to encourage immunogenicity and susceptibility to attack by T lymphocytes and other immune cells (Garnett et al., 2004). For example, irradiated tumor cells can show enhanced expression of the death receptor Fas in vitro and in vivo, consequently sensitizing tumors to antigen-specific cytotoxic T cells and, ultimately, rejection (Chakraborty et al., 2003, 2004).

A case can therefore be made for cancer therapies like RT being able to act as immune adjuvants, in addition to having direct antitumor action (Roses et al., 2008). Such responses must be carefully controlled. Optimization of anti-tumor immune responses following RT is not trivial and requires consideration of many additional contributing factors.

\section{RADIATION AS AN IMMUNE ADJUVANT}

If RT can induce a pro-oxidant, pro-inflammatory microenvironment, one would expect that irradiated tumors often induce measurable systemic immune responses that can lead to tumor regression in preclinical models (Lugade et al., 2005; Lee et al., 2009; Perez et al., 2009; Spanos et al., 2009). There are a few encouraging reports indicating that humans receiving RT may make increased immune responses when combined with other immunostimulatory therapies (Nesslinger et al., 2007; Ferrara et al., 2009; Stamell et al., 2012), with chemotherapy or even alone (Schaue et al., 2008). In the last example, we showed that circulating tumor-specific CD8 + T cells can rise in colorectal cancer patients toward completion of chemo-radiation with $45 \mathrm{~Gy}$ and continuous 5-fluorouracil infusion (Debucquoy et al., 2006, 2009; Schaue et al., 2008). More general support for the view that the immune system can be a powerful and independent prognostic indicator of a good response to cancer therapies comes from studies on T cells infiltration in solid tumors (Galon et al., 2006; Pages et al., 2010) and from abscopal effects that can be attributed to the systemic development of immunity (Formenti and Demaria, 2009; Stamell et al., 2012). Questions however remain as to why tumor-specific responses are not always generated by therapies, even within one tumor type, why some types of tumors generate such responses only rarely, and the ultimate question of why tumors continue to grow even in the presence of an immune response that appears effective in vitro.

One issue that must be considered is that by the time therapy is initiated tumors have already escaped the attentions of the immune system. Multiple mechanisms have been described by which this is achieved (Zitvogel et al., 2006; Whiteside, 2009). The nature of the immune escape mechanism strongly influences the tumor-host relationship, the tumor antigens that are expressed, and probably the outcome of any therapeutic approach. For example, even highly immunogenic tumors can grow progressively and maintain strong tumor antigen expression if they generate powerful suppressor $\mathrm{T}$ cells and macrophages (Howie and McBride, 1982; McBride and Howie, 1986; Iwai et al., 2002). On the other hand, tumors may undergo immunoediting that selects for cells lacking antigen expression during tumor development. In the former situation, tumors are more likely to respond to removal of immune suppressor cells than in the latter. In some tumors, the rate of tumor cell death and turnover could be critical in balancing the immune system so as to favor tumor growth. In this case, simply changing this equation through aggressive therapies may have a positive effect. In each of these scenarios, the tumor antigens that are expressed are likely to differ in potency for stimulating immunity and the suppressor mechanisms that have to be overcome will vary in strength and type. This indicates that different strategies for potentiating tumor immunity may need to be tailored to the existing state of the tumor-host relationship. Additional factors that might limit the generation of the "dangerous" microenvironment and the extent of adaptive immunity to the tumor include the nature of the vasculature, the degree of oxidative stress, and the extent of hypoxia in a tumor (Conejo-Garcia et al., 2004; Rius et al., 2008; Sitkovsky, 2009; Facciabene et al., 2011; Kandalaft et al., 2011). RT has been shown to change the tumor microenvironment by causing vascular damage, inhibiting angiogenesis, and enhancing chronic hypoxia at the expense of transient hypoxia, with the newly generated hypoxic areas becoming infiltrated with tumor-promoting macrophages (Dewhirst et al., 1990; Garcia-Barros et al., 2003; Chen et al., 2009; Ahn et al., 2010; Kioi et al., 2010). These crucial variables may shape the tumor response to RT and vary with the tumor and its location (Chiang et al., 2012).

The dose and delivery schedule for RT also influences the development of anti-tumor immunity. For RT to be an immune adjuvant there seems to be an optimal size of dose and dose per fraction, with moderate dose fractions of around 5-6 Gy being superior to 2 Gy fractions (Dewan et al., 2009; Schaue et al., 2012). And in the case of the murine melanoma model, tumor-specific immune responses following RT were found to inversely correlate with tumor size illustrating an interesting dichotomy in the tumor-host relationship (Schaue et al., 2012). These findings generally support the belief that therapy-induced tumor damage can translate into measurable immune activation.

\section{LIMITING THE IMMUNE RESPONSE TO PROTECT SELF}

The transition from the rapidly generated, innate immune response to activation of the slower, more sophisticated adaptive immune system is a critical step in the development of tumor 
immunity. Importantly, adaptive immunity tends to be polarized, especially with respect to antigen-specific helper and regulatory $\mathrm{T}$ cell subsets (Th/Tregs; Fernandez-Botran et al., 1988) that can ultimately dictate immune-mediated regression or progression, most often mediated through $\mathrm{CD} 8^{+} \mathrm{T}$ cell activation. $\mathrm{CD} 4^{+}$naïve cells (Th0) recognize antigenic peptides on DCs through their T cell receptor- $\mathrm{CD}^{+}$complexes and, based on the signals received, can differentiate along one of at least four pathways to form Th1, Th2, Th17, or iTregs. This dramatic cellular polarization is orchestrated by the prevailing cellular microenvironment through a network of transcription factors and microRNAs; T bet for Th1, GATA-3 for Th2, RORgammat for Th17 cells, and Foxp3, miR-10a, miR-155 for Tregs (Zhu and Paul, 2010; Dang et al., 2011; Gao et al., 2012; Takahashi et al., 2012).

The important result is the emergence of $\mathrm{T}$ cell subsets that, while they are antigen-specific, exert much of their influence through distinctive effector cytokine profiles that influence bystander non-immune and immune cells alike, depending upon their cytokine receptor patterns. Th1 cells respond primarily to IL-12 to produce IFN- $\gamma$, GM-CSF, and TNF- $\alpha$ and are important for assisting cytotoxic $\mathrm{CD}^{+}{ }^{+} \mathrm{T}$ cell-mediated responses that can eliminate tumors. They also activate macrophages to express a pro-inflammatory phenotype that can be cytotoxic to tumors. Th2 cells, in contrast, are stimulated primarily by IL- 4 to produce IL-4, IL-5, IL-6, IL-13, and IL-25. They assist B cells in the generation of antibodies that form allergic responses. Th17 cells differentiate in response to IL-6 or IL-22 to produce IL-17, IL-21, IL-22, IL-23, and GM-CSF. Th17 cells have been implicated in the pathogenesis of many chronic inflammatory and autoimmune diseases (Waite and Skokos, 2012). The concept that distinct functional T cell subsets exist as balanced forces to maintain homeostasis has established validity and has been extended to CD8 ${ }^{+} \mathrm{T}$ cells, "classically" activated M1, and "alternatively" activated M2 macrophages and DC1/DC2 DCs (Czerniecki et al., 2001; Van Ginderachter et al., 2006), although there is some controversy as to the degree of reprogramming that is possible within these other immune cell types.

As crucial for tumor immunity and as life-saving as any of the above immune players are, the mutual antagonism that exists between different Th subsets in itself is insufficient to control the immune system, which can cause extensive tissue damage if left unrestrained, as in chronic inflammation, autoimmune, and allergic reactions. Tregs (also known as suppressor $\mathrm{T}$ cells) are the major players in preventing excessive damage to self (Peterson, 2012) and they represent that other side of the immunological coin from Th cells. The presence of $\mathrm{T}$ cells that could suppress antigen-specific inflammatory $\mathrm{T}$ cell activity was first recognized by Gershon and Kondo (1971), who called the phenomenon "infectious immunological tolerance." Plagued by lack of appropriate markers for $\mathrm{T}$ cell subpopulations, the Treg field fell into disrepute for many years, but re-emerged with the discovery of Tregs that are now known to fall into two major subsets of natural (nTregs) and induced (iTregs). These have largely non-overlapping distinct antigen recognition repertoires (Haribhai et al., 2009, 2011). Unlike Th cells, both Treg subsets focus on recognition of "self" antigens to maintain peripheral immunological tolerance and exert homeostatic control over inflammation through release of immunosuppressive cytokines (Bluestone and Abbas, 2003; Curotto de Lafaille and Lafaille, 2009).

\section{TREGS MAKE US TOLERANT OF OUR SELF AND OF OTHERS}

The importance of Tregs in maintaining peripheral self-tolerance, preventing autoimmune disease, and limiting inflammation and immunity (Sakaguchi, 2004; Shevach, 2004) is exemplified by the havoc caused in their absence, ranging from excessive lymphoproliferation, immune, and inflammatory tissue damage, to death. For example, a loss-of-function mutation in the essential regulator of Tregs, the forkhead box transcription factor Foxp3, leads to a lethal autoimmune and inflammatory disorder in the "scurfy" mouse and the IPEX syndrome (Immune dysregulation Polyendocrinopathy Enteropathy X-linked Syndrome) in humans (Fontenot and Rudensky, 2005; Chatila, 2009). Interesting in this context is the fact that high fractionated doses of radiation delivered to the lymphoid system of mice also generates autoimmunity (Sakaguchi et al., 1994).

Tregs function in widely diverse scenarios to control other $\mathrm{T}$ and B lymphocyte subsets, DCs, and macrophages, as well as nonimmune cells. Although T cell receptor recognition and activation is through cognate antigen, suppression in their immediate environment can be rather indiscriminate, at least in vitro (Shevach, 2009). They use various immunosuppressive effector mechanisms, any one of which may be favored under specific conditions (Pillai et al., 2011). These include cell-to-cell contact, the release of cytokines such as IL-10, IL-4, IL-35, and/or TGF- $\beta$, and the production of adenosine that drives cAMP elevation and inhibition of T effector cells (Chen et al., 2005; von Boehmer, 2005; Deaglio et al., 2007; Shevach, 2009; Efimova et al., 2011). By generating an anti-oxidant/adenosinergic microenvironment, Tregs are tissue protective and the antithesis of pro-oxidant acute inflammation.

Most Tregs are naturally occurring, functionally mature $\mathrm{CD} 4{ }^{+} \mathrm{CD} 25^{\text {hi }}$ Foxp $3{ }^{+}$Tregs (nTregs) that are "hard-wired" with respect to their immune repertoire through thymic development and are already primed for suppressive function. In contrast, $\mathrm{CD} 4{ }^{+} \mathrm{CD} 25^{-}$naïve $\mathrm{T}$ cells can be converted outside the thymus into $\mathrm{CD} 4{ }^{+} \mathrm{CD} 25^{\text {hi }} \mathrm{Foxp}^{+}$Tregs, and are therefore called inducible or adaptive, iTregs. Induction can be a result of exposure to low doses of antigen, IL-2, and TGF- $\beta$ (Apostolou and von Boehmer, 2004; Curotto de Lafaille et al., 2004). Given these differences in origin, it is not surprising that recombinase-deficient mice can generate iTregs but have no nTregs (Curotto de Lafaille et al., 2001; Mucida et al., 2005).

The functional distinction between iTregs and nTregs has still to be fully established, but they do not share the same workload in controlling the adaptive immune response. Overall, the regulatory phenotype of iTregs and their Foxp3 expression is less stable than that of nTregs possibly due to differences in epigenetic regulation and microRNA miR-10a availability (Floess et al., 2007; Takahashi et al., 2012). Their gene expression profiles are not identical (Feuerer et al., 2010). Molecular studies indicate that nTregs, but not iTregs, express Helios, an Ikaros family transcription factor (Thornton et al., 2010) and are activated by TNF- $\alpha$ (Housley et al., 2011) and by IL-6, the latter converting them to Th17 cells that can mediate potentially pathogenic autoimmunity (Xu et al., 2007). iTregs resist such Th17 conversion (Zheng et al., 


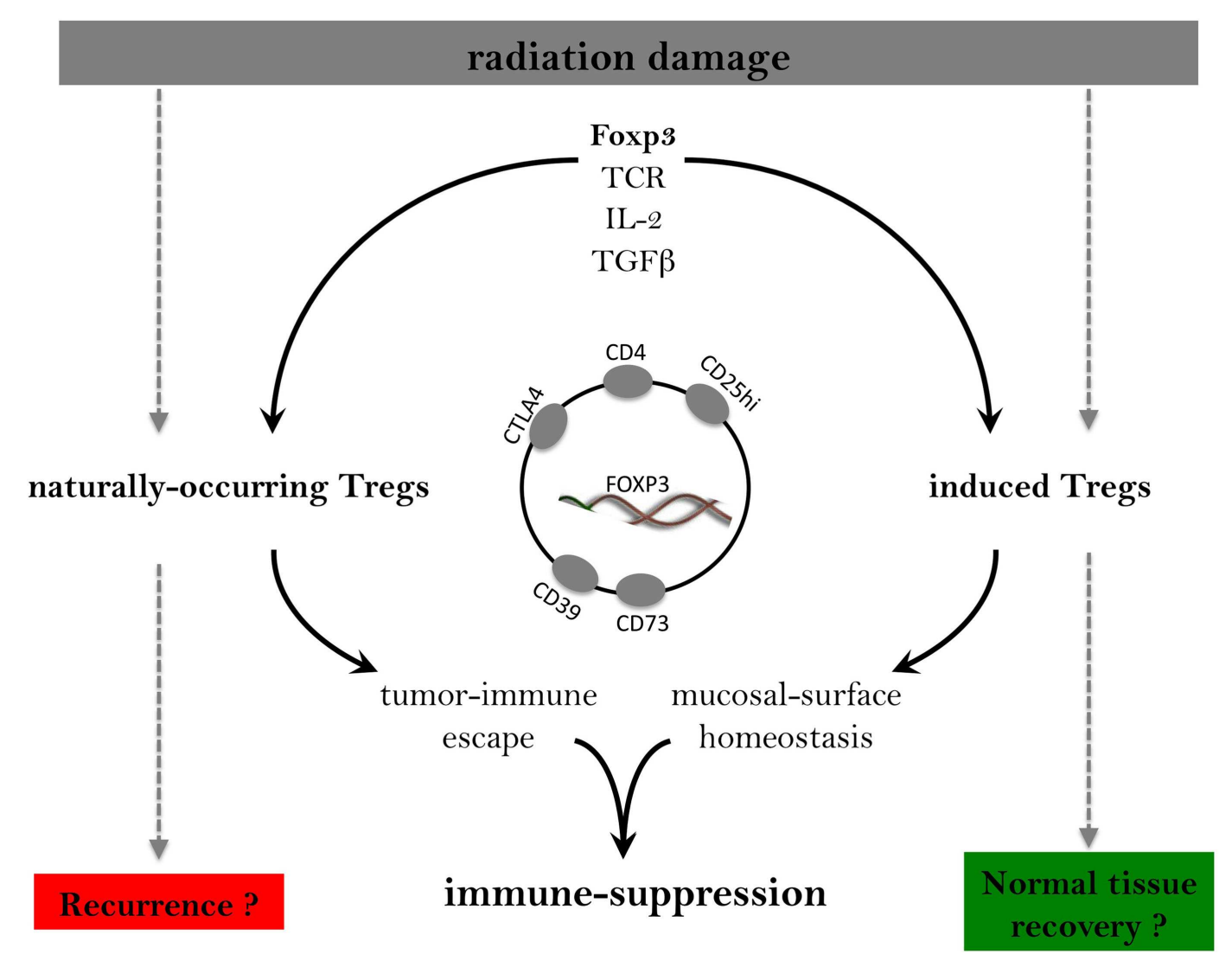

FIGURE 1 | Systemic immune control is exerted through the combined effort of thymically derived, naturally occurring $n$ Tregs, and peripherally induced iTregs that have specificity for "self" antigens but with distinct, minimally overlapping TCR repertoires. Both Treg pools depend heavily on the transcription factor FoxP3 and on IL-2 with TGF- $\beta$ providing additional stimulation. While both Treg subsets contribute to immune suppression, iTregs seem to be selectively involved in mucosal surfaces. Radiation therapy drives an increase in Tregs that may limit potential anti-tumor immunity and aid tumor escape on one side but that may also nurture normal tissue recovery on the other.
2008). These differences may be important in that there is some evidence that iTregs exert control of inflammatory responses at normal mucosal surfaces while nTregs appear more important for mediating self-tolerance and tumor immune escape (Sakaguchi, 2004, 2005; Curotto de Lafaille and Lafaille, 2009; Haribhai et al., 2011; Rosenblum et al., 2011; Josefowicz et al., 2012; Figure 1). There is a distinct possibility that RT might differentially affect these Treg subpopulations, but this has yet to be established.

\section{RADIATION EFFECTS ON IMMUNITY IN VIVO}

The concept that RT is purely immunosuppressive because lymphocytes are very radiation sensitive is out-moded. While scientific wisdom indicates that lymphocytes are very radiosensitive, subsets differ in this regard and because all immune cells can be induced by radiation itself, as well as by DAMPs, cytokines, and other stimuli to respond at the molecular level, RT is clearly better regarded as being immunomodulatory. In very general terms, a spectrum of radiosensitivity exists from B cells through naive Th cells, NK cells, T memory cells (Belka et al., 1999), Tregs, and DCs to radioresistant macrophages, with a tendency toward apoptosis denoting a more radiosensitive phenotype and non-proliferative cells and activated lymphocytes being more radioresistant (McBride et al.,
2004). As a result of blood flow through the field, even local RT will have a purely physical cytotoxic effect of the circulating immunocyte pool, which will vary with the tissue, and the delivery time and dose. Induced responses in tumor and normal tissues, and in the immune cells themselves add considerable additional complexity to the immune equation. The usual radiobiological parameters such as dose, dose rate, fraction size, and radiation quality are pertinent in all cases. Further, if chemotherapy is also given, different drugs are expected to target different immune cell populations, again with dose and scheduling being important parameters.

The ability of radiation to differentially modulate $\mathrm{T}$ cell subsets was in fact observed by North, Hellstroem, and others more than 30 years ago. They showed that sublethal, whole-body irradiation eliminated suppressor $\mathrm{T}$ cells leading to partial or complete tumor regression in immuno-competent, but not in immunoincompetent, mice (Hellstrom et al., 1978; Tilkin et al., 1981; North, 1986). The same subset appeared sensitive to low dose cyclophosphamide (Bonavida et al., 1979; Awwad and North, 1989). This introduced the concept of metronomic low dose chemotherapy treatment that might assist elimination of immune suppressor cells, but angiogenesis and other cells are also possible targets (Penel et al., 2012). In contrast to these studies, we 
and others have shown that Tregs are relatively radioresistant (Kusunoki et al., 2010; Nakatsukasa et al., 2010; Qu et al., 2010; Weng et al., 2010; Kachikwu et al., 2011). A possible explanation for this discrepancy lies in the fact that the timing of the radiation exposure post-tumor implantation was critical in North's experiments and that a Treg subpopulation may have been induced that became sensitive to radiation. Although Tregs have often been considered inherently anergic, robust Treg proliferation has been observed after stimulation (Walker, 2004). The sensitivity of Tregs to chemo- and radiotherapy in cancer patients is of great clinical interest but largely unknown. The suggestion is that there are immune mechanisms of action as an alternative to direct cytotoxicity, although at present there are no definitive data. In fact, there may be other immune targets such as the myeloid cells that can be induced following RT and whose elimination enhances radiation-induced tumor regression (Ahn et al., 2010).

What we do know is that the tumor-specific immune responses made by cancer patients receiving RT appear to be held in check by increases in the systemic Treg pool (Schaue et al., 2008). We have seen this phenomenon also in murine tumor models mice treated with radiation (Schaue et al., 2012). Interestingly, radiation can increase Treg representation even in the absence of a tumor (Cao et al., 2009; Kusunoki et al., 2010; Nakatsukasa et al., 2010; Qu et al., 2010; Billiard et al., 2011; Kachikwu et al., 2011). This can be interpreted as a response to control radiationinduced inflammation and normal tissue damage. One possible mechanism is through induction and activation of the powerful immune-suppressive cytokine TGF- $\beta$ by RT (Martin et al., 2000), which is known to boost Tregs (Chen et al., 2003; Beal et al., 2012; Takahashi et al., 2012). In addition, we were able to detect radiation-enhanced expression of the ectonucleotidase CD39 on the Treg population, which has also been observed in treated cancer patients (Mandapathil et al., 2009). Adenosine production through nucleotide catabolism by CD39 and CD73 is probably the most primitive immunosuppressive response to "danger." Adenosine has long been known to play a critical, non-redundant role in the protection of normal tissues from collateral damage during inflammation (Cronstein, 1994), including radiation-induced tissue damage (Hosek et al., 1992; Pospisil et al., 1993, 1998; Hou et al., 2007), where it plays a protective role (Hofer et al., 2002). Support for this scenario comes from the observation that tissue derived adenosine acting through its receptor $A_{2 A} R$ drives Tregs and limits autoimmune tissue destruction (Zarek et al., 2008).

\section{INHIBIT THE INHIBITORS TO WIDEN THE RADIOTHERAPEUTIC WINDOW?}

The existence of tumor-induced immunosuppressive $\mathrm{T}$ cells and myeloid cells has been known for decades (Howie and McBride, 1982) and Tregs may influence the development of suppressor macrophages through cytokine release. It has taken longer for the concept that the immune system is under continuous negative regulation to be recognized and that loss of these important control mechanisms under steady state conditions can augment inflammation and autoimmunity. Importantly, tools are now available for investigating the role of these subsets in RT settings and for modifying their influence.
There are numerous reports that myeloid-derived suppressor cells (MDSC) and Treg levels are elevated in the peripheral circulation of cancer patients. They are also increased in lymphoid organs and tumors of tumor-bearing mice (Howie and McBride, 1982; Chen et al., 2009). Further, systemic depletion of Foxp $3^{+}$Tregs enhances natural as well as vaccine-induced anti-tumor $\mathrm{T}$ cell responses (Liyanage et al., 2002; Curiel et al., 2004; Dannull et al., 2005; Miller et al., 2006), as does targeting CD11b ${ }^{+}$myeloid cells (Ahn et al., 2010). It is now generally accepted that a rise in MDSC or Tregs in a patient's blood or tumor is often associated with poor outcome and that this can be attributed to their immunosuppressive and/or tumor growth promoting effects. The possible exceptions are colorectal and head and neck cancers (Ladoire et al., 2011; Deleeuw et al., 2012), which may indicate greater microbial involvement in these sites. Also, it is difficult to reliably conclude that a rise in Tregs is a negative prognostic indicator if simultaneous measurements are not made in cytotoxic immune cells, the reason being that any pro-inflammatory response is likely to solicit an adaptive compensatory response (Litjens et al., 2012; Tang et al., 2012). In this sense, Tregs may be considered as another immunological readout that mirrors the development of cytotoxic effector $\mathrm{T}$ cells, further supporting the general thesis that radiation can be an immune adjuvant (Schaue et al., 2008). Both Tregs and myeloid suppressor cells may be viewed as wound healing responses to tissue damage, only in this case the damage is caused by tumor growth.

From an immunological perspective, the challenge for cancer $\mathrm{RT}$ is to create an immunologically permissive environment. This is complex with many pre-existing and induced negative regulatory barriers to be overcome. The size of the challenge will vary with the pre-existing tumor-host environment, the clinical stage and type of tumor, the condition of the patient, and many other variables. These hurdles will vary in height and it may not be possible to generate observable responses in all cases. However, some approaches to unmasking the adjuvanticity of RT show considerable promise.

One of the most effective ways to overcome such barriers is through broad Treg targeting with anti-CD25 antibody and/or immunotoxin or anti-CTLA-4 antibody (Leach et al., 1996; Rasku et al., 2008; Hodi et al., 2010; Byrne et al., 2011; Mellman et al., 2011). Enhanced anti-tumor immunity in general and the effectiveness of RT in particular have been shown (Demaria et al., 2005; Kachikwu et al., 2011; Postow et al., 2012). Currently, the extent of any Treg subset selectivity in these approaches is not known, nor whether radiation-induced normal tissue complications are increased. The use of anti-CTLA-4 as a monotherapy (Phan et al., 2003; O'Day et al., 2007; Yang et al., 2007; Weber et al., 2009), for example, is associated with some toxicity and should be used with caution when combined with other therapies. Furthermore, there are suggestions that Foxp3 may not always be a desirable target in every cancer setting because Foxp $3^{+} \mathrm{T}$ cell infiltration does not always predict poor prognosis, for example in colorectal cancer, and because Foxp3 appears to act as a tumor suppressor gene when expressed in non-immune tissues (Deleeuw et al., 2012; McInnes et al., 2012). The influence of myeloid cells may be decreased by colony stimulating pathways on which they depend (Ahn et al., 2010; Vincent et al., 2010), but once RT or 
chemotherapy is over, both are likely to rebound, which may be the best time to target these brakes on the development of antitumor immunity. The potential power of these immunological approaches is very appealing and they may be enhanced even more in the future by more selective targeting of tumor-specific Treg TCRs with antibodies to eliminate those driving immune suppression or with cytokines that could enhance macrophage

\section{REFERENCES}

Ahn, G. O., Tseng, D., Liao, C. H., Dorie, M. J., Czechowicz, A., and Brown, J. M. (2010). Inhibition of Mac-1 (CD11b/CD18) enhances tumor response to radiation by reducing myeloid cell recruitment. Proc. Natl. Acad. Sci. U.S.A. 107, 8363-8368.

Apetoh, L., Ghiringhelli, F., Tesniere, A., Obeid, M., Ortiz, C., Criollo, A., Mignot, G., Maiuri, M. C., Ullrich, E., Saulnier, P., Yang, H., Amigorena, S., Ryffel, B., Barrat, F. J., Saftig, P., Levi, F., Lidereau, R., Nogues, C., Mira, J. P., Chompret, A., Joulin, V., Clavel-Chapelon, F., Bourhis, J., Andre, F., Delaloge, S., Tursz, T., Kroemer, G., and Zitvogel, L. (2007). Toll-like receptor 4-dependent contribution of the immune system to anticancer chemotherapy and radiotherapy. Nat. Med. 13, 1050-1059.

Apostolou, I., and von Boehmer, $\mathrm{H}$. (2004). In vivo instruction of suppressor commitment in naive $\mathrm{T}$ cells. J. Exp. Med. 199, 1401-1408.

Awwad, M., and North, R. J. (1989). Cyclophosphamide-induced immunologically mediated regression of a cyclophosphamideresistant murine tumor: a consequence of eliminating precursor L3T4+ suppressor T-cells. Cancer Res. 49, 1649-1654.

Banchereau, J., and Steinman, R. M. (1998). Dendritic cells and the control of immunity. Nature 392, 245-252.

Beal, A. M., Ramos-Hernandez, N., Riling, C. R., Nowelsky, E. A., and Oliver, P. M. (2012). TGF-beta induces the expression of the adaptor Ndfip1 to silence IL-4 production during iT(reg) cell differentiation. Nat. Immunol. 13, 77-85.

Belka, C., Ottinger, H., Kreuzfelder, E., Weinmann, M., Lindemann, M., Lepple-Wienhues, A., Budach, W., Grosse-Wilde, H., and Bamberg, M. (1999). Impact of localized radiotherapy on blood immune cells counts and function in humans. Radiother. Oncol. 50, 199-204.

Beutler, B. A. (2009). TLRs and innate immunity. Blood 113, 1399-1407.

Billiard, F., Buard, V., Benderitter, M., and Linard, C. (2011). Abdominal gamma-radiation induces an accumulation of function-impaired regulatory $\mathrm{T}$ cells in the small intestine. Int. J. Radiat. Oncol. Biol. Phys. 80, 869-876.

Bluestone, J. A., and Abbas, A. K. (2003). Natural versus adaptive regulatory $\mathrm{T}$ cells. Nat. Rev. Immunol. 3, 253-257. Bonavida, B., Hutchinson, I. V., and Thomas, A. (1979). Cyclophosphamide-sensitive and cyclophosphamide-resistant suppressor cells in the immune response to alloantigens. Transplant. Proc. 11, 874-877.

Burnette, B. C., Liang, H., Lee, Y., Chlewicki, L., Khodarev, N. N., Weichselbaum, R. R., Fu, Y. X., and Auh, S. L. (2011). The efficacy of radiotherapy relies upon induction of type i interferon-dependent innate and adaptive immunity. Cancer Res. 71, 2488-2496.

Byrne, W. L., Mills, K. H., Lederer, J. A., and O'Sullivan, G. C. (2011). Targeting regulatory $\mathrm{T}$ cells in cancer. Cancer Res. 71, 6915-6920.

Cao, M., Cabrera, R., Xu, Y., Liu, C., and Nelson, D. (2009). Gamma irradiation alters the phenotype and function of CD4+CD25+ regulatory $\mathrm{T}$ cells. Cell Biol. Int. 33, 565-571.

Chakraborty, M., Abrams, S. I., Camphausen, K., Liu, K., Scott, T., Coleman, C. N., and Hodge, J. W. (2003). Irradiation of tumor cells up-regulates Fas and enhances CTL lytic activity and CTL adoptive immunotherapy. J. Immunol. 170, 6338-6347.

Chakraborty, M., Abrams, S. I., Coleman, C. N., Camphausen, K., Schlom, J., and Hodge, J. W. (2004). External beam radiation of tumors alters phenotype of tumor cells to render them susceptible to vaccinemediated T-cell killing. Cancer Res. 64, 4328-4337.

Chatila, T. A. (2009). Regulatory $\mathrm{T}$ cells: key players in tolerance and autoimmunity. Endocrinol. Metab. Clin. North Am. 38, 265-272, vii.

Chen, F. H., Chiang, C. S., Wang, C. C., Tsai, C. S., Jung, S. M., Lee, C. C., McBride, W. H., and Hong, J. H. (2009). Radiotherapy decreases vascular density and causes hypoxia

anti-tumor action or drive Tregs into an effector mode (Byrne et al., 2011).

\section{ACKNOWLEDGMENTS}

The authors were supported by the NIH 2U19 AI67769 (William H. McBride and Dörthe Schaue) and DOD W81XWH-10-10424 (Dörthe Schaue).

with macrophage aggregation in TRAMP-C1 prostate tumors. Clin. Cancer Res. 15, 1721-1729.

Chen, M. L., Pittet, M. J., Gorelik, L., Flavell, R. A., Weissleder, R., von Boehmer, H., and Khazaie, K. (2005). Regulatory T cells suppress tumor-specific CD8 T cell cytotoxicity through TGF-beta signals in vivo. Proc. Natl. Acad. Sci. U.S.A. 102, 419-424.

Chen, W., Jin, W., Hardegen, N., Lei, K. J., Li, L., Marinos, N., McGrady, G., and Wahl, S. M. (2003). Conversion of peripheral CD4+CD25- naive $\mathrm{T}$ cells to $\mathrm{CD} 4+\mathrm{CD} 25+$ regulatory $\mathrm{T}$ cells by TGF-beta induction of transcription factor Foxp3. J. Exp. Med. 198, 1875-1886.

Chiang, C. S., Fu, S. Y., Wang, S. C., Yu, C. F., Chen, F. H., Ling, C. M., and Hong, J. H. (2012). Irradiation promotes M2 macrophages toward hypoxia. Front. Oncol. 2:89. doi:10.3389/fonc.2012.00089

Conejo-Garcia, J. R., Benencia, F., Courreges, M. C., Kang, E., MohamedHadley, A., Buckanovich, R. J., Holtz, D. O., Jenkins, A., Na, H., Zhang, L., Wagner, D. S., Katsaros, D., Caroll, R., and Coukos, G. (2004). Tumorinfiltrating dendritic cell precursors recruited by a beta-defensin contribute to vasculogenesis under the influence of Vegf-A. Nat. Med. 10, 950-958.

Cronstein, B. N. (1994). Adenosine, an endogenous anti-inflammatory agent. J. Appl. Physiol. 76, 5-13.

Curiel, T. J., Coukos, G., Zou, L., Alvarez, X., Cheng, P., Mottram, P., EvdemonHogan, M., Conejo-Garcia, J. R., Zhang, L., Burow, M., Zhu, Y., Wei, S., Kryczek, I., Daniel, B., Gordon, A., Myers, L., Lackner, A., Disis, M. L., Knutson, K. L., Chen, L., and Zou, W. (2004). Specific recruitment of regulatory $\mathrm{T}$ cells in ovarian carcinoma fosters immune privilege and predicts reduced survival. Nat. Med. 10, 942-949.

Curotto de Lafaille, M. A., and Lafaille, J. J. (2009). Natural and adaptive foxp $3+$ regulatory $\mathrm{T}$ cells: more of the same or a division of labor? Immunity 30, 626-635.

Curotto de Lafaille, M. A., Lino, A. C., Kutchukhidze, N., and Lafaille,
J. J. (2004). CD25- T cells generate CD25+Foxp3+ regulatory T cells by peripheral expansion. J. Immunol. 173, 7259-7268.

Curotto de Lafaille, M. A., Muriglan, S., Sunshine, M. J., Lei, Y., Kutchukhidze, N., Furtado, G. C., Wensky, A. K., Olivares-Villagomez, D., and Lafaille, J. J. (2001). Hyper immunoglobulin E response in mice with monoclonal populations of $\mathrm{B}$ and T lymphocytes. J. Exp. Med. 194, 1349-1359.

Curtin, J. F., Liu, N., Candolfi, M., Xiong, W., Assi, H., Yagiz, K., Edwards, M. R., Michelsen, K. S., Kroeger, K. M., Liu, C., Muhammad, A. K., Clark, M. C., Arditi, M., Comin-Anduix, B., Ribas, A., Lowenstein, P. R., and Castro, M. G. (2009). HMGB1 mediates endogenous TLR2 activation and brain tumor regression. PLoS Med. 6, e10. doi:10.1371/journal.pmed.1000010

Czerniecki, B. J., Cohen, P. A., Faries, M., $\mathrm{Xu}$, S., Roros, J. G., and Bedrosian, I. (2001). Diverse functional activity of CD83+ monocyte-derived dendritic cells and the implications for cancer vaccines. Crit. Rev. Immunol. 21, 157-178.

Dang, E. V., Barbi, J., Yang, H. Y., Jinasena, D., Yu, H., Zheng, Y., Bordman, Z., Fu, J., Kim, Y., Yen, H. R., Luo, W., Zeller, K., Shimoda, L., Topalian, S. L., Semenza, G. L., Dang, C. V., Pardoll, D. M., and Pan, F. (2011). Control of $\mathrm{T}(\mathrm{H}) 17 / \mathrm{T}$ (reg) balance by hypoxia-inducible factor 1. Cell 146, 772-784.

Dannull, J., Su, Z., Rizzieri, D., Yang, B. K., Coleman, D., Yancey, D. Zhang, A., Dahm, P., Chao, N., Gilboa, E., and Vieweg, J. (2005). Enhancement of vaccine-mediated antitumor immunity in cancer patients after depletion of regulatory $\mathrm{T}$ cells. J. Clin. Invest. 115, 3623-3633.

Deaglio, S., Dwyer, K. M., Gao, W., Friedman, D., Usheva, A., Erat, A., Chen, J. F., Enjyoji, K., Linden, J., Oukka, M., Kuchroo, V. K., Strom, T. B., and Robson, S. C. (2007). Adenosine generation catalyzed by CD39 and CD73 expressed on regulatory $\mathrm{T}$ cells mediates immune suppression. J. Exp. Med. 204, 1257-1265. 
Debucquoy, A., Goethals, L., Geboes, K., Roels, S., McBride, W. H., and Haustermans, K. (2006). Molecular responses of rectal cancer to preoperative chemoradiation. Radiother. Oncol. 80, 172-177.

Debucquoy, A., Roels, S., Goethals, L., Libbrecht, L., Van Cutsem, E., Geboes, K., Penninckx, F., D'Hoore, A., McBride, W. H., and Haustermans, K. (2009). Double blind randomized phase II study with radiation+5-fluorouracil+/celecoxib for resectable rectal cancer. Radiother. Oncol. 93, 273-278.

Deleeuw, R. J., Kost, S. E., Kakal, J. A., and Nelson, B. H. (2012). The prognostic value of FoxP3+ tumorinfiltrating lymphocytes in cancer: a critical review of the literature. Clin. Cancer Res. 18, 3022-3029.

Demaria, S., Kawashima, N., Yang, A. M., Devitt, M. L., Babb, J. S., Allison, J. P., and Formenti, S. C. (2005). Immune-mediated inhibition of metastases after treatment with local radiation and CTLA4 blockade in a mouse model of breast cancer. Clin. Cancer Res. 11, 728-734.

Dewan, M. Z., Galloway, A. E., Kawashima, N., Dewyngaert, J. K., Babb, J. S., Formenti, S. C., and Demaria, S. (2009). Fractionated but not single-dose radiotherapy induces an immune-mediated abscopal effect when combined with anti-CTLA-4 antibody. Clin. Cancer Res. 15, 5379-5388.

Dewhirst, M. W., Oliver, R., Tso, C. Y., Gustafson, C., Secomb, T., and Gross, J. F. (1990). Heterogeneity in tumor microvascular response to radiation. Int. J. Radiat. Oncol. Biol. Phys. 18, 559-568.

Efimova, O., Szankasi, P., and Kelley, T. W. (2011). Ncf1 (p47phox) is essential for direct regulatory $\mathrm{T}$ cell mediated suppression of $\mathrm{CD} 4+$ effector T cells. PLoS ONE 6, el6013. doi:10.1371/journal.pone.0016013

Facciabene, A., Peng, X., Hagemann, I. S., Balint, K., Barchetti, A., Wang, L. P., Gimotty, P. A., Gilks, C. B., Lal, P., Zhang, L., and Coukos, G. (2011). Tumour hypoxia promotes tolerance and angiogenesis via CCL28 and T(reg) cells. Nature 475, 226-230.

Fernandez-Botran, R., Sanders, V. M., Mosmann, T. R., and Vitetta, E. S. (1988). Lymphokine-mediated regulation of the proliferative response of clones of T helper 1 and $\mathrm{T}$ helper 2 cells. J. Exp. Med. 168, 543-558.

Ferrara, T. A., Hodge, J. W., and Gulley, J. L. (2009). Combining radiation and immunotherapy for synergistic antitumor therapy. Curr. Opin. Mol. Ther. 11, 37-42.

Feuerer, M., Hill, J. A., Kretschmer, K., von Boehmer, H., Mathis, D., and Benoist, C. (2010). Genomic definition of multiple ex vivo regulatory $\mathrm{T}$ cell subphenotypes. Proc. Natl. Acad. Sci. U.S.A. 107, 5919-5924.

Floess, S., Freyer, J., Siewert, C., Baron, U., Olek, S., Polansky, J., Schlawe, K., Chang, H. D., Bopp, T., Schmitt, E., Klein-Hessling, S., Serfling, E., Hamann, A., and Huehn, J. (2007). Epigenetic control of the foxp3 locus in regulatory T cells. PLoS Biol. 5, e38. doi:10.1371/journal.pbio.0050038

Fontenot, J. D., and Rudensky, A. Y. (2005). A well adapted regulatory contrivance: regulatory $\mathrm{T}$ cell development and the forkhead family transcription factor Foxp3. Nat. Immunol. 6, 331-337.

Formenti, S. C., and Demaria, S. (2009). Systemic effects of local radiotherapy. Lancet Oncol. 10, 718-726.

Gallucci, S., Lolkema, M., and Matzinger, P. (1999). Natural adjuvants: endogenous activators of dendritic cells. Nat. Med. 5, 1249-1255.

Galon, J., Costes, A., Sanchez-Cabo, F., Kirilovsky, A., Mlecnik, B., LagorcePages, C., Tosolini, M., Camus, M., Berger, A., Wind, P., Zinzindohoue, F., Bruneval, P., Cugnenc, P. H., Trajanoski, Z., Fridman, W. H., and Pages, F. (2006). Type, density, and location of immune cells within human colorectal tumors predict clinical outcome. Science 313, 1960-1964.

Gao, Y., Lin, F., Su, J., Gao, Z., Li, Y., Yang, J., Deng, Z., Liu, B., Tsun, A., and Li, B. (2012). Molecular mechanisms underlying the regulation and functional plasticity of FOXP3(+) regulatory T cells. Genes Immun. 13, 1-13.

Garcia-Barros, M., Paris, F., CordonCardo, C., Lyden, D., Rafii, S., Haimovitz-Friedman, A., Fuks, Z., and Kolesnick, R. (2003). Tumor response to radiotherapy regulated by endothelial cell apoptosis. Science 300, 1155-1159.

Garnett, C. T., Palena, C., Chakraborty, M., Tsang, K. Y., Schlom, J., and Hodge, J. W. (2004). Sublethal irradiation of human tumor cells modulates phenotype resulting in enhanced killing by cytotoxic T lymphocytes. Cancer Res. 64, 7985-7994.

Gershon, R. K., and Kondo, K. (1971). Infectious immunological tolerance. Immunology 21, 903-914.

Haribhai, D., Lin, W., Edwards, B., Ziegelbauer, J., Salzman, N. H.,
Carlson, M. R., Li, S. H., Simpson, P. M., Chatila, T. A., and Williams, C. B. (2009). A central role for induced regulatory $\mathrm{T}$ cells in tolerance induction in experimental colitis. J. Immunol. 182, 3461-3468.

Haribhai, D., Williams, J. B., Jia, S., Nickerson, D., Schmitt, E. G., Edwards, B., Ziegelbauer, J., Yassai, M., Li, S. H., Relland, L. M., Wise, P. M., Chen, A., Zheng, Y. Q., Simpson, P. M., Gorski, J., Salzman, N. H., Hessner, M. J., Chatila, T. A., and Williams, C. B. (2011). A requisite role for induced regulatory $\mathrm{T}$ cells in tolerance based on expanding antigen receptor diversity. Immunity 35 , 109-122.

Hellstrom, K. E., Hellstrom, I., Kant, J. A., and Tamerius, J. D. (1978). Regression and inhibition of sarcoma growth by interference with a radiosensitive T-cell population. $J$. Exp. Med. 148, 799-804.

Hodi, F. S., O'Day, S. J., McDermott, D. F., Weber, R. W., Sosman, J. A., Haanen, J. B., Gonzalez, R., Robert, C., Schadendorf, D., Hassel, J. C., Akerley, W., van den Eertwegh, A. J., Lutzky, J., Lorigan, P., Vaubel, J. M., Linette, G. P., Hogg, D., Ottensmeier, C. H., Lebbe, C., Peschel, C., Quirt, I., Clark, J. I., Wolchok, J. D., Weber, J. S., Tian, J., Yellin, M. J., Nichol, G. M., Hoos, A., and Urba, W. J. (2010). Improved survival with ipilimumab in patients with metastatic melanoma. N. Engl. J. Med. 363, 711-723.

Hofer, M., Pospisil, M., Znojil, V., Vacek, A., Weiterova, L., Hola, J., and Vacha, J. (2002). Drugs elevating extracellular adenosine promote regeneration of haematopoietic progenitor cells in severely myelosuppressed mice: their comparison and joint effects with the granulocyte colony-stimulating factor. Eur. J. Haematol. 68, 4-11.

Hosek, B., Bohacek, J., Sikulova, J. Pospisil, M., and Vacek, A. (1992). Protection of early cellular damage in 1 Gy-irradiated mice by the elevation of extracellular adenosine. Radiat. Environ. Biophys. 31, 289-297.

Hou, B., Xu, Z. W., Yang, C. W., Gao, Y., Zhao, S. F., and Zhang, C. G. (2007). Protective effects of inosine on mice subjected to lethal total-body ionizing irradiation. J. Radiat. Res. 48, 57-62.

Housley, W. J., Adams, C. O., Nichols, F. C., Puddington, L., Lingenheld, E. G., Zhu, L., Rajan, T. V., and Clark, R. B. (2011). Natural but not inducible regulatory $\mathrm{T}$ cells require TNF-alpha signaling for in vivo function. J. Immunol. 186, 6779-6787.
Howie, S., and McBride, W. H. (1982). Tumor-specific T helper activity can be abrogated by two distinct suppressor cell mechanisms. Eur. J. Immunol. 12, 671-675.

Iwai, Y., Ishida, M., Tanaka, Y., Okazaki, T., Honjo, T., and Minato, N. (2002). Involvement of PD-L1 on tumor cells in the escape from host immune system and tumor immunotherapy by PD-L1 blockade. Proc. Natl. Acad. Sci. U.S.A. 99, 12293-12297.

Josefowicz, S. Z., Niec, R. E., Kim, H. Y., Treuting, P., Chinen, T., Zheng, Y., Umetsu, D. T., and Rudensky, A. Y. (2012). Extrathymically generated regulatory $\mathrm{T}$ cells control mucosal TH2 inflammation. Nature 482, 395-399.

Kachikwu, E. L., Iwamoto, K. S., Liao, Y. P., Demarco, J. J., Agazaryan, N., Economou, J. S., McBride, W. H., and Schaue, D. (2011). Radiation enhances regulatory $\mathrm{T}$ Cell representation. Int. J. Radiat. Oncol. Biol. Phys. 81, 1128-1135.

Kandalaft, L. E., Motz, G. T., Busch, J., and Coukos, G. (2011). Angiogenesis and the tumor vasculature as antitumor immune modulators: the role of vascular endothelial growth factor and endothelin. Curr. Top. Microbiol. Immunol. 344, 129-148.

Kawai, T., and Akira, S. (2011). Tolllike receptors and their crosstalk with other innate receptors in infection and immunity. Immunity 34, 637-650.

Kioi, M., Vogel, H., Schultz, G., Hoffman, R. M., Harsh, G. R., and Brown, J. M. (2010). Inhibition of vasculogenesis, but not angiogenesis, prevents the recurrence of glioblastoma after irradiation in mice. J. Clin. Invest. 120, 694-705.

Kusunoki, Y., Yamaoka, M., Kubo, Y., Hayashi, T., Kasagi, F., Douple, E. B., and Nakachi, K. (2010). T-cell immunosenescence and inflammatory response in atomic bomb survivors. Radiat. Res. 174, 870-876.

Ladoire, S., Martin, F., and Ghiringhelli, F. (2011). Prognostic role of FOXP3 + regulatory T cells infiltrating human carcinomas: the paradox of colorectal cancer. Cancer Immunol. Immunother. 60, 909-918.

Leach, D. R., Krummel, M. F., and Allison, J. P. (1996). Enhancement of antitumor immunity by CTLA-4 blockade. Science 271, 1734-1736.

Lee, Y., Auh, S. L., Wang, Y., Burnette, B., Meng, Y., Beckett, M., Sharma, R., Chin, R., Tu, T., Weichselbaum, R. R., and Fu, Y. X. (2009). Therapeutic effects of ablative radiation on local tumor require $\mathrm{CD} 8+\mathrm{T}$ 
cells: changing strategies for cancer treatment. Blood 114, 589-595.

Litjens, N. H., Boer, K., and Betjes, M. G. (2012). Identification of circulating human antigen-reactive $\mathrm{CD} 4+\mathrm{FOXP} 3+$ natural regulatory $\mathrm{T}$ cells. J. Immunol. 188, 1083-1090.

Liyanage, U. K., Moore, T. T., Joo, H. G., Tanaka, Y., Herrmann, V., Doherty, G., Drebin, J. A., Strasberg, S. M., Eberlein, T. J., Goedegebuure, P. S., and Linehan, D. C. (2002). Prevalence of regulatory $T$ cells is increased in peripheral blood and tumor microenvironment of patients with pancreas or breast adenocarcinoma. J. Immunol. 169, 2756-2761.

Lorimore, S. A., Coates, P. J., Scobie, G. E., Milne, G., and Wright, E. G. (2001). Inflammatory-type responses after exposure to ionizing radiation in vivo: a mechanism for radiation-induced bystander effects? Oncogene 20, 7085-7095.

Lotze, M. T., Zeh, H. J., Rubartelli, A., Sparvero, L. J., Amoscato, A. A., Washburn, N. R., Devera, M. E., Liang, X., Tor, M., and Billiar, T. (2007). The grateful dead: damageassociated molecular pattern molecules and reduction/oxidation regulate immunity. Immunol. Rev. 220, 60-81.

Lugade, A. A., Moran, J. P., Gerber, S. A., Rose, R. C., Frelinger, J. G., and Lord, E. M. (2005). Local radiation therapy of B16 melanoma tumors increases the generation of tumor antigen-specific effector cells that traffic to the tumor. J. Immunol. 174, 7516-7523.

Lugade, A. A., Sorensen, E. W., Gerber, S. A., Moran, J. P., Frelinger, J. G., and Lord, E. M. (2008). Radiationinduced IFN-gamma production within the tumor microenvironment influences antitumor immunity. J. Immunol. 180, 3132-3139.

Mandapathil, M., Szczepanski, M. J., Szajnik, M., Ren, J., Lenzner, D. E., Jackson, E. K., Gorelik, E., Lang, S., Johnson, J. T., and Whiteside, T. L. (2009). Increased ectonucleotidase expression and activity in regulatory $\mathrm{T}$ cells of patients with head and neck cancer. Clin. Cancer Res. 15, 6348-6357.

Martin, M., Lefaix, J., and Delanian, S. (2000). TGF-betal and radiation fibrosis: a master switch and a specific therapeutic target? Int. J. Radiat. Oncol. Biol. Phys. 47, 277-290.

Matsumura, S., Wang, B., Kawashima, N., Braunstein, S., Badura, M., Cameron, T. O., Babb, J. S., Schneider, R. J., Formenti, S. C., Dustin, M. L., and Demaria, S. (2008).
Radiation-induced CXCL16 release by breast cancer cells attracts effector T cells. J. Immunol. 181, 3099-3107. Matzinger, P. (2002). The danger model: a renewed sense of self. Science 296, 301-305.

McBride, W. H., Chiang, C. S., Olson, J. L., Wang, C. C., Hong, J. H., Pajonk, F., Dougherty, G. J., Iwamoto, K. S., Pervan, M., and Liao, Y. P. (2004). A sense of danger from radiation. Radiat. Res. 162, 1-19.

McBride, W. H., and Howie, S. E. (1986). Induction of tolerance to a murine fibrosarcoma in two zones of dosage - the involvement of suppressor cells. Br. J. Cancer 53, 707-711.

McInnes, N., Sadlon, T. J., Brown, C. Y., Pederson, S., Beyer, M., Schultze, J. L., McColl, S., Goodall, G. J., and Barry, S. C. (2012). FOXP3 and FOXP3-regulated microRNAs suppress SATB1 in breast cancer cells. Oncogene 31, 1045-1054.

Medzhitov, R., Preston-Hurlburt, P., and Janeway, C. A. Jr. (1997). A human homologue of the Drosophila Toll protein signals activation of adaptive immunity. Nature 388, 394-397.

Mellman, I., Coukos, G., and Dranoff, G. (2011). Cancer immunotherapy comes of age. Nature 480, 480-489.

Meylan, E., Tschopp, J., and Karin, M. (2006). Intracellular pattern recognition receptors in the host response. Nature 442, 39-44.

Miller, A. M., Lundberg, K., Ozenci, V., Banham, A. H., Hellstrom, M., Egevad, L., and Pisa, P. (2006). CD4+CD25 high $\mathrm{T}$ cells are enriched in the tumor and peripheral blood of prostate cancer patients. J. Immunol. 177, 7398-7405.

Morel, A., Fernandez, N., de La Coste, A., Haddada, H., Viguier, M., Polla, B. S., Antoine, B., and Kahn, A. (1998). Gamma-ray irradiation induces B7.1 costimulatory molecule neoexpression in various murine tumor cells. Cancer Immunol. Immunother. 46, 277-282.

Mucida, D., Kutchukhidze, N., Erazo, A., Russo, M., Lafaille, J. J., and Curotto de Lafaille, M. A. (2005). Oral tolerance in the absence of naturally occurring Tregs. J. Clin. Invest. 115, 1923-1933.

Nakatsukasa, H., Tsukimoto, M., Tokunaga, A., and Kojima, S. (2010). Repeated gamma irradiation attenuates collagen-induced arthritis via up-regulation of regulatory $\mathrm{T}$ cells but not by damaging lymphocytes directly. Radiat. Res. 174, 313-324.

Nesslinger, N. J., Sahota, R. A., Stone, B., Johnson, K., Chima, N., King,
C., Rasmussen, D., Bishop, D., Rennie, P. S., Gleave, M., Blood, P., Pai, H., Ludgate, C., and Nelson, B. H. (2007). Standard treatments induce antigen-specific immune responses in prostate cancer. Clin. Cancer Res. 13, 1493-1502.

North, R. J. (1986). Radiation-induced, immunologically mediated regression of an established tumor as an example of successful therapeutic immunomanipulation. Preferential elimination of suppressor $\mathrm{T}$ cells allows sustained production of effector T cells. J. Exp. Med. 164, 1652-1666.

O'Day, S. J., Hamid, O., and Urba, W. J. (2007). Targeting cytotoxic Tlymphocyte antigen-4 (CTLA-4): a novel strategy for the treatment of melanoma and other malignancies. Cancer 110, 2614-2627.

Pages, F., Galon, J., Dieu-Nosjean, M. C., Tartour, E., Sautes-Fridman, C. and Fridman, W. H. (2010). Immune infiltration in human tumors: a prognostic factor that should not be ignored. Oncogene 29, 1093-1102.

Penel, N., Adenis, A., and Bocci, G. (2012). Cyclophosphamide-based metronomic chemotherapy: after 10 years of experience, where do we stand and where are we going? Crit. Rev. Oncol. Hematol. 82, 40-50.

Perez, C. A., Fu, A., Onishko, H., Hallahan, D. E., and Geng, L. (2009). Radiation induces an antitumour immune response to mouse melanoma. Int. J. Radiat. Biol. 85, 1126-1136.

Peterson, R. A. (2012). Regulatory Tcells: diverse phenotypes integral to immune homeostasis and suppression. Toxicol. Pathol. 40, 186-204.

Phan, G. Q., Yang, J. C., Sherry, R. M., Hwu, P., Topalian, S. L., Schwartzentruber, D. J., Restifo, N. P., Haworth, L. R., Seipp, C. A., Freezer, L. J., Morton, K. E., Mavroukakis, S. A., Duray, P. H., Steinberg, S. M., Allison, J. P., Davis, T. A., and Rosenberg, S. A. (2003). Cancer regression and autoimmunity induced by cytotoxic $\mathrm{T}$ lymphocyte-associated antigen 4 blockade in patients with metastatic melanoma. Proc. Natl. Acad. Sci. U.S.A. 100, 8372-8377.

Pillai, M. R., Collison, L. W., Wang, X., Finkelstein, D., Rehg, J. E., Boyd, K., Szymczak-Workman, A. L., Doggett, T., Griffith, T. S., Ferguson, T. A., and Vignali, D. A. (2011). The plasticity of regulatory $\mathrm{T}$ cell function. $J$. Immunol. 187, 4987-4997.

Pospisil, M., Hofer, M., Netikova, J., Pipalova, I., Vacek, A., Bartonickova, A., and Volenec, K. (1993). Elevation of extracellular adenosine induces radioprotective effects in mice. Radiat. Res. 134, 323-330.

Pospisil, M., Hofer, M., Znojil, V., Netikova, J., Vacha, J., Hola, J., and Vacek, A. (1998). Granulocyte colony-stimulating factor and drugs elevating extracellular adenosine synergize to enhance haematopoietic reconstitution in irradiated mice. Eur. J. Haematol. 60, 172-180.

Postow, M. A., Callahan, M. K., Barker, C. A., Yamada, Y., Yuan, J., Kitano, S., Mu, Z., Rasalan, T., Adamow, M., Ritter, E., Sedrak, C., Jungbluth, A. A., Chua, R., Yang, A. S., Roman, R. A., Rosner, S., Benson, B., Allison, J. P., Lesokhin, A. M., Gnjatic, S., and Wolchok, J. D. (2012). Immunologic correlates of the abscopal effect in a patient with melanoma. N. Engl. J. Med. 366, 925-931.

Qu, Y., Jin, S., Zhang, A., Zhang, B., Shi, X., Wang, J., and Zhao, Y. (2010). Gamma-ray resistance of regulatory CD4+CD25+Foxp3+ T cells in mice. Radiat. Res. 173, 148-157.

Rasku, M.A., Clem, A. L., Telang, S., Taft, B., Gettings, K., Gragg, H., Cramer, D., Lear, S. C., McMasters, K. M., Miller, D. M., and Chesney, J. (2008). Transient $\mathrm{T}$ cell depletion causes regression of melanoma metastases. J. Transl. Med. 6, 12.

Reits, E. A., Hodge, J. W., Herberts, C. A., Groothuis, T. A., Chakraborty, M., Wansley, E. K., Camphausen, K., Luiten, R. M., de Ru, A. H., Neijssen, J., Griekspoor, A., Mesman, E., Verreck, F. A., Spits, H., Schlom, J., van Veelen, P., and Neefjes, J. J. (2006). Radiation modulates the peptide repertoire, enhances $\mathrm{MHC}$ class I expression, and induces successful antitumor immunotherapy. J. Exp. Med. 203, 1259-1271.

Rius, J., Guma, M., Schachtrup, C., Akassoglou, K., Zinkernagel, A. S., Nizet, V., Johnson, R. S., Haddad, G. G., and Karin, M. (2008). NFkappaB links innate immunity to the hypoxic response through transcriptional regulation of HIF-lalpha. Nature 453, 807-811.

Robinson, M. J., Sancho, D., Slack, E. C., LeibundGut-Landmann, S., and Reis e Sousa, C. (2006). Myeloid Ctype lectins in innate immunity. Nat. Immunol. 7, 1258-1265.

Rosenblum, M. D., Gratz, I. K., Paw, J. S., Lee, K., Marshak-Rothstein, A., and Abbas, A. K. (2011). Response to self antigen imprints regulatory memory in tissues. Nature 480, 538-542.

Roses, R. E., Xu, M., Koski, G. K., and Czerniecki, B. J. (2008). Radiation therapy and Toll-like receptor signaling: implications for the 
treatment of cancer. Oncogene 27, 200-207.

Sakaguchi, N., Miyai, K., and Sakaguchi, S. (1994). Ionizing radiation and autoimmunity. Induction of autoimmune disease in mice by high dose fractionated total lymphoid irradiation and its prevention by inoculating normal $\mathrm{T}$ cells. J. Immunol. 152, 2586-2595.

Sakaguchi, S. (2004). Naturally arising $\mathrm{CD} 4+$ regulatory $\mathrm{t}$ cells for immunologic self-tolerance and negative control of immune responses. Annu. Rev. Immunol. 22, 531-562.

Sakaguchi, S. (2005). Naturally arising Foxp3-expressing CD25+CD4+ regulatory $\mathrm{T}$ cells in immunological tolerance to self and non-self. Nat. Immunol. 6, 345-352.

Santin, A. D., Hiserodt, J. C., Fruehauf, J., DiSaia, P. J., Pecorelli, S., and Granger, G. A. (1996). Effects of irradiation on the expression of surface antigens in human ovarian cancer. Gynecol. Oncol. 60, 468-474.

Sato, Y., Goto, Y., Narita, N., and Hoon, D. S. (2009). Cancer cells expressing toll-like receptors and the tumor microenvironment. Cancer Microenviron. 2(Suppl. 1), 205-214.

Schaue, D., Comin-Anduix, B., Ribas, A., Zhang, L., Goodglick, L., Sayre, J. W., Debucquoy, A., Haustermans, K., and McBride, W. H. (2008). Tcell responses to survivin in cancer patients undergoing radiation therapy. Clin. Cancer Res. 14, 4883-4890.

Schaue, D., Kachikwu, E. L., and McBride, W. H. (in press). Cytokines in radiobiological responses: a review. Radiat. Res.

Schaue, D., and McBride, W. H. (2010). Links between innate immunity and normal tissue radiobiology. Radiat. Res. 173, 406-417.

Schaue, D., Ratikan, J. A., Iwamoto, K. S., and McBride, W. H. (2012). Maximizing tumor immunity with fractionated radiation. Int. J. Radiat. Oncol. Biol. Phys. 83, 1306-1310.

Seo, A., Ishikawa, F., Nakano, H., Nakazaki, H., Kobayashi, K., and Kakiuchi, T. (1999). Enhancement of B7-1 (CD80) expression on B-lymphoma cells by irradiation. Immunology 96, 642-648.

Shevach, E. M. (2004). Regulatory/suppressor $\mathrm{T}$ cells in health and disease. Arthritis Rheum. 50, 2721-2724.

Shevach, E. M. (2009). Mechanisms of foxp $3+\mathrm{T}$ regulatory cell-mediated suppression. Immunity 30, 636-645.
Shi, Y., Evans, J. E., and Rock, K. L. (2003). Molecular identification of a danger signal that alerts the immune system to dying cells. Nature 425, 516-521.

Sitkovsky, M. V. (2009). T regulatory cells: hypoxia-adenosinergic suppression and re-direction of the immune response. Trends Immunol. 30, 102-108.

Spanos, W. C., Nowicki, P., Lee, D. W., Hoover, A., Hostager, B., Gupta, A., Anderson, M. E., and Lee, J. H. (2009). Immune response during therapy with cisplatin or radiation for human papillomavirusrelated head and neck cancer. Arch. Otolaryngol. Head Neck Surg. 135, 1137-1146.

Stamell, E. F., Wolchok, J. D., Gnjatic, S., Lee, N. Y., and Brownell, I. (2012). The abscopal effect associated with a systemic anti-melanoma immune response. Int. J. Radiat. Oncol. Biol. Phys.

Steinman, R. M., Hawiger, D., and Nussenzweig, M. C. (2003). Tolerogenic dendritic cells. Annu. Rev. Immunol. 21, 685-711.

Takahashi, H., Kanno, T., Nakayamada, S., Hirahara, K., Sciume, G., Muljo, S. A., Kuchen, S., Casellas, R., Wei, L., Kanno, Y., and O'Shea, J. J. (2012). TGF-beta and retinoic acid induce the microRNA miR-10a, which targets Bcl- 6 and constrains the plasticity of helper T cells. Nat. Immunol. 13, 587-595.

Tang, S., Moore, M. L., Grayson, J. M., and Dubey, P. (2012). Increased CD8+ T-cell function following castration and immunization is countered by parallel expansion of regulatory T cells. Cancer Res. 72, 1975-1985.

Thornton, A. M., Korty, P. E., Tran, D. Q., Wohlfert, E. A., Murray, P. E., Belkaid, Y., and Shevach, E. M. (2010). Expression of Helios, an Ikaros transcription factor family member, differentiates thymic-derived from peripherally induced Foxp $3+\mathrm{T}$ regulatory cells. J. Immunol. 184, 3433-3441.

Tilkin, A. F., Schaaf-Lafontaine, N., Van Acker, A., Boccadoro, M., and Urbain, J. (1981). Reduced tumor growth after low-dose irradiation or immunization against blastic suppressor T cells. Proc. Natl. Acad. Sci. U.S.A. 78, 1809-1812.

Tyurina, Y. Y., Tyurin, V. A., Kapralova, V. I., Wasserloos, K., Mosher, M., Epperly, M. W., Greenberger, J. S., Pitt, B. R., and Kagan, V. E. (2011).
Oxidative lipidomics of gammaradiation-induced lung injury: mass spectrometric characterization of cardiolipin and phosphatidylserine peroxidation. Radiat. Res. 175, 610-621.

Ullrich, E., Bonmort, M., Mignot, G., Kroemer, G., and Zitvogel, L. (2008). Tumor stress, cell death and the ensuing immune response. Cell Death Differ. 15, 21-28.

Van Ginderachter, J. A., Movahedi, K., Hassanzadeh Ghassabeh, G., Meerschaut, S., Beschin, A., Raes, G., and De Baetselier, P. (2006). Classical and alternative activation of mononuclear phagocytes: picking the best of both worlds for tumor promotion. Immunobiology 211, 487-501.

Vincent, J., Mignot, G., Chalmin, F., Ladoire, S., Bruchard, M., Chevriaux, A., Martin, F., Apetoh, L., Rebe, C., and Ghiringhelli, F. (2010). 5-Fluorouracil selectively kills tumor-associated myeloidderived suppressor cells resulting in enhanced $\mathrm{T}$ cell-dependent antitumor immunity. Cancer Res. 70, 3052-3061.

von Boehmer, H. (2005). Mechanisms of suppression by suppressor T cells. Nat. Immunol. 6, 338-344.

Waite, J. C., and Skokos, D. (2012). Th17 response and inflammatory autoimmune diseases. Int. J. Inflamm. 2012, 819467.

Walker, L. S. (2004). CD4+ CD25+ Treg: divide and rule? Immunology 111, 129-137.

Weber, J., Thompson, J. A., Hamid, O., Minor, D., Amin, A., Ron, I., Ridolfi, R., Assi, H., Maraveyas, A., Berman, D., Siegel, J., and O'Day, S. J. (2009). A randomized, doubleblind, placebo-controlled, phase II study comparing the tolerability and efficacy of ipilimumab administered with or without prophylactic budesonide in patients with unresectable stage III or IV melanoma. Clin. Cancer Res. 15, 5591-5598.

Weng, L., Williams, R. O., Vieira, P. L., Screaton, G., Feldmann, M., and Dazzi, F. (2010). The therapeutic activity of low-dose irradiation on experimental arthritis depends on the induction of endogenous regulatory T cell activity. Ann. Rheum. Dis. 69, 1519-1526.

Whiteside, T. L. (2009). Tricks tumors use to escape from immune control. Oral Oncol. 45, e119-e123.

Xu, L., Kitani, A., Fuss, I., and Strober, W. (2007). Cutting edge: regulatory $\mathrm{T}$ cells induce CD4+CD25-Foxp3-
T cells or are self-induced to become Th17 cells in the absence of exogenous TGF-beta. J. Immunol. 178, 6725-6729.

Yang, J. C., Hughes, M., Kammula, U., Royal, R., Sherry, R. M., Topalian, S. L., Suri, K. B., Levy, C., Allen, T., Mavroukakis, S., Lowy, I., White, D. E., and Rosenberg, S. A. (2007). Ipilimumab (anti-CTLA4 antibody) causes regression of metastatic renal cell cancer associated with enteritis and hypophysitis. J. Immunother. 30, 825-830.

Zarek, P. E., Huang, C. T., Lutz, E. R., Kowalski, J., Horton, M. R., Linden, J., Drake, C. G., and Powell, J. D. (2008). A2A receptor signaling promotes peripheral tolerance by inducing T-cell anergy and the generation of adaptive regulatory T cells. Blood 111, 251-259.

Zheng, S. G., Wang, J., and Horwitz, D. A. (2008). Cutting edge: Foxp3+CD4+CD25+ regulatory $\mathrm{T}$ cells induced by IL- 2 and TGF-beta are resistant to Th17 conversion by IL-6. J. Immunol. 180, 7112-7116.

Zhu, J., and Paul, W. E. (2010). Peripheral CD4+ T-cell differentiation regulated by networks of cytokines and transcription factors. Immunol. Rev. 238, 247-262.

Zitvogel, L., Tesniere, A., and Kroemer, G. (2006). Cancer despite immunosurveillance: immunoselection and immunosubversion. Nat. Rev. Immunol. 6, 715-727.

Conflict of Interest Statement: The authors declare that the research was conducted in the absence of any commercial or financial relationships that could be construed as a potential conflict of interest.

Received: 15 June 2012; accepted: 20 July 2012; published online: 17 August 2012. Citation: Schaue D, Xie MW, Ratikan JA and McBride WH (2012) Regulatory $T$ cells in radiotherapeutic responses. Front. Oncol. 2:90. doi: 10.3389/fonc. 2012.00090

This article was submitted to Frontiers in Radiation Oncology, a specialty of Frontiers in Oncology.

Copyright (c) 2012 Schaue, Xie, Ratikan and McBride. This is an open-access article distributed under the terms of the Creative Commons Attribution License, which permits use, distribution and reproduction in other forums, provided the original authors and source are credited and subject to any copyright notices concerning any third-party graphics etc. 